\title{
The first record of a potential pest Orientus ishidae (Matsumura, 1902) (Hemiptera: Cicadellidae) in Poland
}

\author{
Tomasz Klejdysz ${ }^{1 *}$, Agnieszka Zwolińska ${ }^{2}$, Marcin Walczak ${ }^{3}$, Michał Kobiałka ${ }^{4}$ \\ ${ }^{1}$ Department of Entomology, Institute of Plant Protection - National Research Institute, Władysława Węgorka 20, 60-318 Poznań, \\ Poland \\ ${ }^{2}$ Department of Virology and Bacteriology, Institute of Plant Protection - National Research Institute, Władysława Węgorka 20, \\ 60-318 Poznań, Poland \\ ${ }^{3}$ Department of Zoology, Faculty of Biology and Environmental Protection, University of Silesia in Katowice, Bankowa 9, \\ 40-007 Katowice, Poland \\ ${ }^{4}$ Department of Developmental Biology and Morphology of Invertebrates, Institute of Zoology, Jagiellonian University, \\ Gronostajowa 9, 30-387 Kraków, Poland
}

Vol. 57, No. 2: 107-112, 2017

DOI: 10.1515/jppr-2017-0014

Received: November 16, 2016

Accepted: March 11, 2017

*Corresponding address:

t.klejdysz@iorpib.poznan.pl

\begin{abstract}
This study provides the first data on the occurrence of the mosaic leafhopper Orientus ishidae (Matsumura, 1902) (Hemiptera: Cicadellidae) in Poland. This species is native to Southeast Asia, adventive in Europe and feeds on cultivated plants. Orientus ishidae is a well-known carrier of Grapevine flavescence doree phytoplasma which causes the grapevine yellows disease. Symptoms of phytoplasma diseases of grapevine include deformations, leaf chlorosis and withering of plants. The appearance of this species in Poland might be caused by observed climate variations and insufficient plant health controls in the international trade of plants.
\end{abstract}

Key words: biodiversity, first record, leafhopper, Orientus ishidae, pest

\section{Introduction}

The number of alien leafhopper species has increased in Poland and also in other European countries over the last few years. Four adventive leafhopper species, which have adapted to new environments, have been recorded in Poland over the last two decades. These are: Graphocephala fennahi Young, 1977 (Łabanowski and Soika 1998), Stictocephala bisonia Kopp \& Yonke, 1977 (Świerczewski and Stroiński 2011), Japananus hyalinus (Osborn, 1900) (Walczak et al. 2012) and Eupteryx decemnotata Rey, 1891 (Lubiasz and Musik 2015). The leafhopper Orientus ishidae (Matsumura, 1902) (Fig. 1) is the next alien species that has not been reported in Poland before.

The genus Orientus DeLong, 1938 (Family: Cicadellidae Latreille, 1825; subfamily: Deltocephalinae Fieber, 1869; tribus: Athysanini Van Duzee, 1892), is represented by two species: Orientus ishidae (Matsumura, 1902) and the recently described Orientus amurensis
Guglielmino, 2005. Both species are very similar to each other, with respect to size, body proportions and color. Orientus ishidae differs from O. amurensis by having very long and thin processes of pygofer (Fig. 3: 6), the presence of a tooth on genital plates (Fig. 3: 3), long and slender styles (Fig. 3: 4, 5) and massive and wide aedeagus (Fig. 3: 1, 2) (Guglielmino 2005). Orientus ishidae so far has been found in Japan (Hokkaido, Honshu, Kyushu and Shikoku), Taiwan, Korea and the Philippine Islands (Metcalf 1967). It has been introduced into North America and Europe. In North America the species was recorded in the USA - New Jersey, New York, Maryland, Pennsylvania, Long Island, New Hampshire, District of Columbia, Ohio, Connecticut (Metcalf 1967) and in Canada (Hamilton 1983). Data on the first record of this species in Europe were provided by Guglielmino (2005), who observed it in Italy in 1998. It has expanded its range and covers 


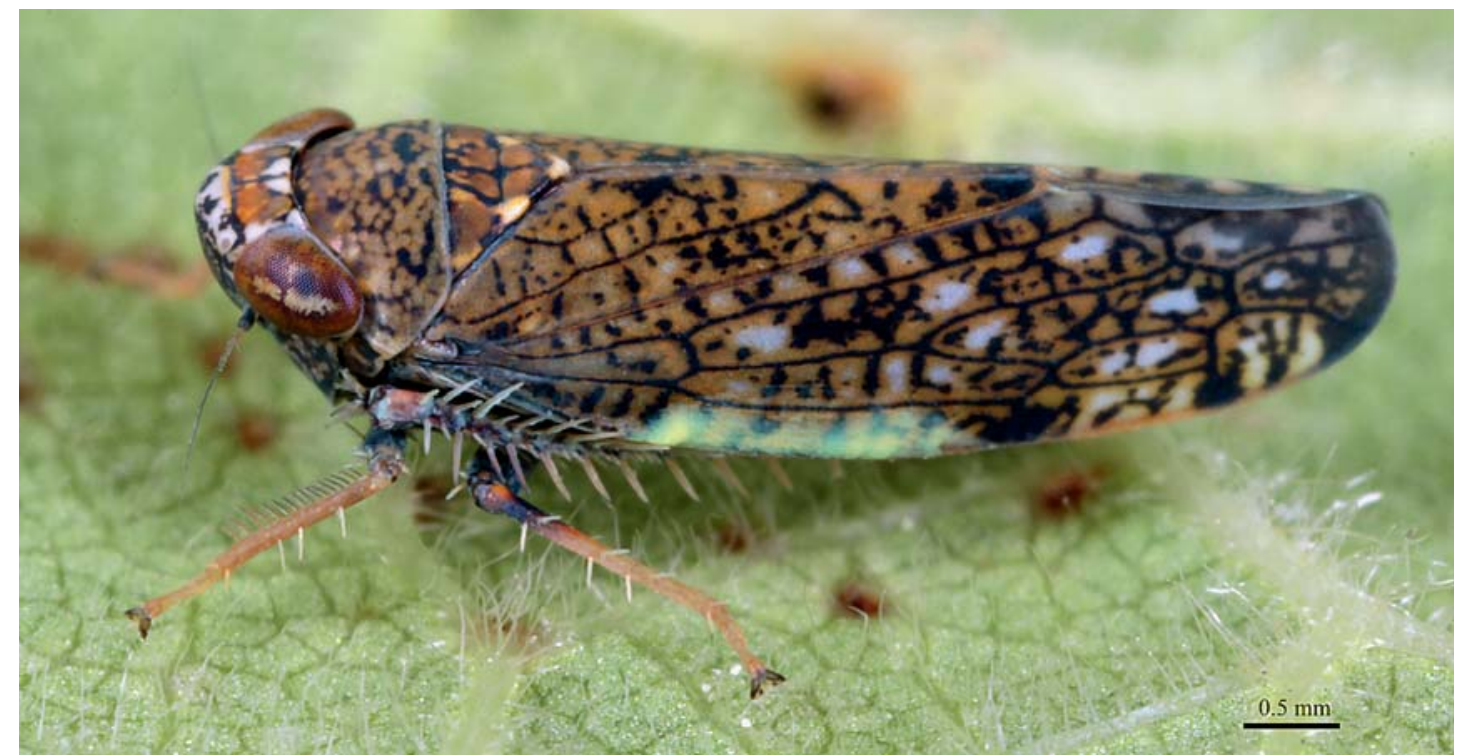

Fig. 1. Mosaic leafhopper - Orientus ishidae on a hazel leaf (Corylus avellana) in Poznań, Poland

the following European countries: Czech Republic in 2004 (Malenovsky and Lauterer 2010), Austria in 2007 (Nickel 2010), France in 2009 (Callot and Brua 2013), Hungary in 2010 (Koczor et al. 2013), Great Britain in 2011 (Anonymous 2012), Slovenia (Jurc 2010), Switzerland (Günthart and Mühlethaler 2002) and Germany in 2002 (Nickel 2010). There is some information posted on internet forums on the occurrence of $O$. ishidae in Belgium, Slovakia and Spain (Anonymous 2015).

Orientus amurensis was described by Guglielmino (2005) in Eastern Russia (Maritime Territory) and China (Liaoning Province). It can be found on various trees and shrubs - oak, willow and legumes. This species inhabits broadleaved forests on herbaceous plants and diverse shrubs (Vilbaste 1968; Anufriev 1978).

The mosaic leafhopper is relatively large (up to $6.5 \mathrm{~mm}$ long) and possesses characteristic coloration (Fig. 1). The surface of the body is covered with a mosaic black line pattern on a creamy brown background. Adult insects emerge in the first half of July and are observed till late October. It has one generation per year and overwinters as eggs, which are inserted into plant tissues (Nickel 2010).

Like other representatives of its family, O. ishidae is a plant sap feeder, obtaining phloem sap by piercing vascular tissue. The mosaic leafhopper is a polyphagous species. It feeds on many species of trees, bushes and herbs. So far this species has been found feeding on: barberry (Berberis spp.), common box (Buxus sempervirens), greater celandine (Chelidonium majus), common beech (Fagus sylvatica), birches (Betula spp., mainly on Betula pendula), hornbeams (Carpinus betulus), common hazel (Corylus avellana), European hophornbeam (Ostrya carpinifolia), ash (Juglans regia), Eastern black walnut (Juglans nigra), field elm (Ulmus minor), stinging nettle (Urtica dioica), willows (Salix alba, S. babylonica, S. caprea, S. purpurea, S. x rubens), black poplar 'Italica' (Populus nigra italica), dog-rose (Rosa canina), orchard apple (Malus domestica and other apple trees - Malus spp.), plum (Prunus domestica), cherry laurel (Laurocerasus officinalis), midland hawthorn (Crataegus oxyacantha), blackberry (Rubus fruticosus), maples (Acer spp., mainly on Acer campestre), common dogwood (Cornus sanguinea), devil's walkingstick (Aralia spinose), common ivy (Hedera helix), common grape vine (Vitis vinifera) and laurustinus viburnum (Viburnum tinus) (Sanders and DeLong 1919; Oman 1949; Ishihara 1968; Vilbaste 1968; Hamilton 1985; Seljak 2004; Guglielmino 2005; Mazzoni 2005; Nickel 2010; Lessio et al. 2016). In Poland O. ishidae has been recorded on: pedunculate oak (Quercus robur), elms (Ulmus spp.), midland hawthorn (Crataegus oxyacantha), low juneberry (Amelanchier spicata) and common hazel (Corylus avellana).

\section{Materials and Methods}

The discovery of $O$. ishidae in Poland resulted from the collection and observation of adult insects. We employed common collecting methods used in applied entomology. These included light trapping with an artificial light source ( $250 \mathrm{~W}$ mercury bulb), an entomological umbrella and visual examination of host plants. Orientus ishidae was captured in a trap designed to catch the forest pest Zeiraphera griseana (Hübner, 1799) (Lepidoptera: Tortricidae). We took advantage of the fact that insects are attracted to light and caught some specimens inside a house.

Specimens were identified using the identification key by Guglielmino (2005), by comparing the genital 


\section{PAN}

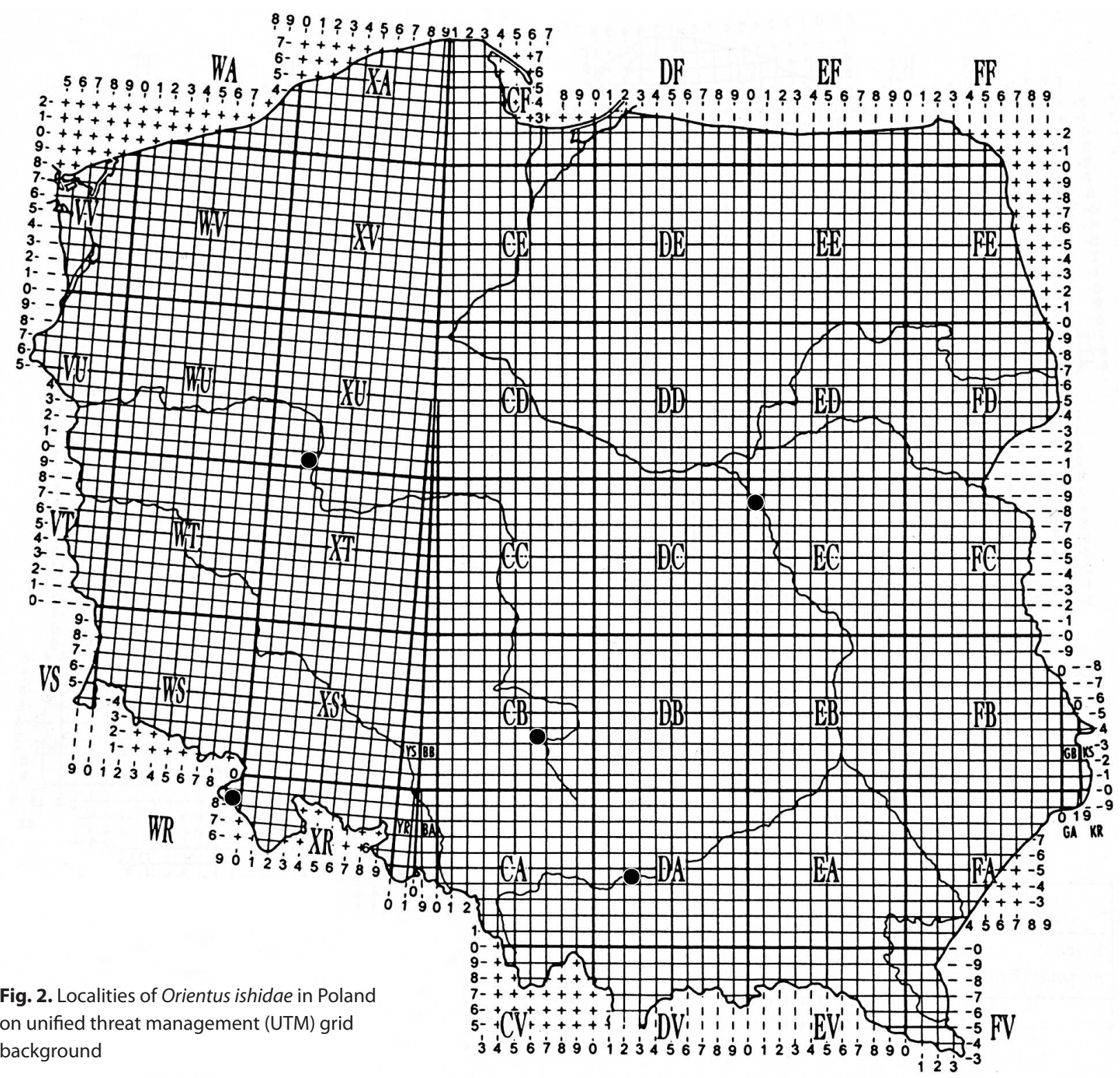

segment (pygofer) and male genitalia of collected individuals with the drawings included in the key.

Our assessment of the pathogenicity for cultivated plants in Poland was based on a precise analysis of the scientific literature dealing with the ability of $O$. ishidae to transmit plant pathogens and also an analysis of the list of host plants.

The distribution of this species in Poland is presented on the unified threat management (UTM) map and the division of Poland into zoogeographical regions is adopted from a series of Catalogues of Polish Fauna (Burakowski et al. 1973).

\section{Results}

Orientus ishidae has been found only in urban areas. The species has seldom been detected outside the city limits. It is attracted to artificial light sources and enters apartments through open windows during the evening and at night. It moves towards light traps and screens illuminated by the artificial light of a mercury vapor lamp (Nickel 2010).

Localities of O. ishidae (Matsumura, 1902) in Poland (Fig. 2):

- Mazowiecka Lowland - Warszawa UTM: EC08, 17 VII 2014: 1 , , collected in an apartment of a residential building on Jan Nowak Street, Murat R. leg., Klejdysz T. det. et coll.; 23 VIII 2015, 2 exx collected in an apartment of a residential building, Jan Nowak Street, Murat R., observation;

- Wielkopolsko-Kujawska Lowland - Poznań UTM: XU20, light trap, 3/4 VIII 2015: 20ิ ठै; 8/9 VIII

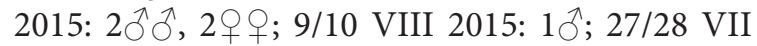

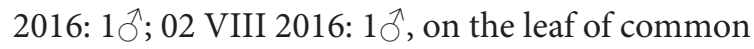
hazel (Corylus avellana L.) in orchard, Klejdysz T. leg., det. et coll.;

- Western Sudetes Mts - Lewin Kłodzki UTM: WR98, Forest Inspectorate of Lewin, district 94c, 


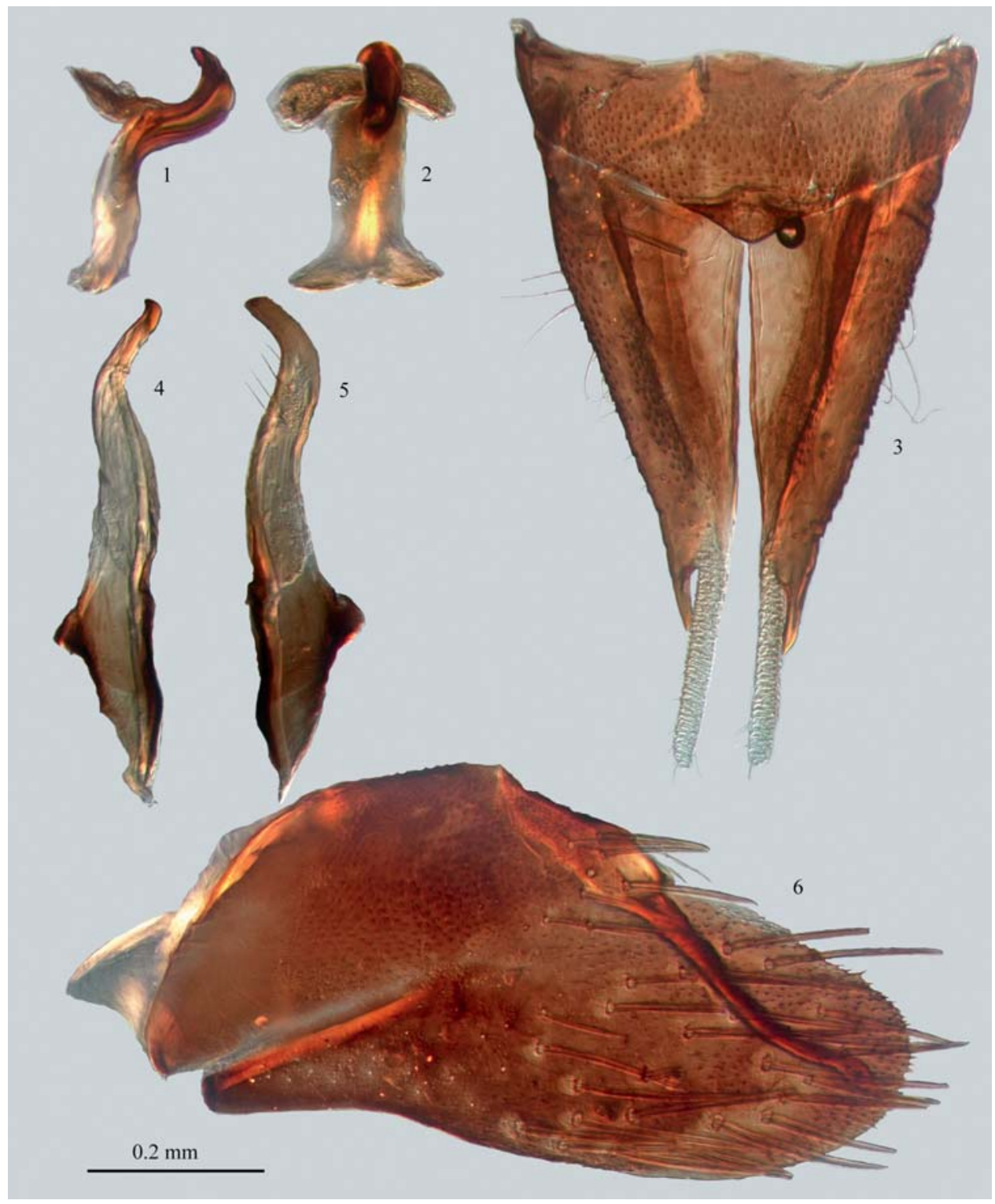

Fig. 3. Apex of male abdomen of Orientus ishidae: aedeagus, lateral view - 1; aedeagus, posterior view - 2; abdominal sternite, genital plates and valves, ventral view - 3; right genital style, lateral view - 4; right genital style, dorsal view -5 ; pygofer with process, side view -6 .

10 VII 2014: 1 , sticky trap for catching grey larch tortrix (Zeiraphera griseana (Hüb.)) hung in a 100-year old spruce stand, Bruder D. leg., Klejdysz T. det. et coll.;

- Krakowsko-Wieluńska Upland - Kraków, Różana Street, UTM: DA24, 7 VIII 2015: $10^{\hat{1}}$ in an apartment, it flew in through the window in the evening, Kobiałka M. leg., Walczak M. det. et coll.; Kraków, Gronostajowa Street, near the Jagiellonian University Campus, 14 IX 2015: $1 \hat{\jmath}, 3$ 우 collected from hawthorn (Crataegus sp.), leg. Walczak M. \& Kobiałka M., Walczak M. det. et coll.; Częstochowa, Wyczerpy-Aniołów district, 'Las Aniołowski' Recreational Park, UTM: CB63, 20 VIII 2016, 10, 1 , , on Ulmus sp., leg., det. et coll. Walczak M.; 24 VIII 2016,

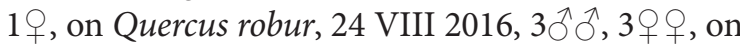
Amelanchier spicata, leg., det. et coll. Walczak M.

\section{Discussion}

Research on $O$. ishidae as a potential vector of plant pathogens shows that this species might become a pest of cultivated plants in Poland. A broad range of host plants enables the insect to change its feeding behavior during a vegetation season, which favors the spread of plant pathogens that cause plant diseases. Although the $16 \mathrm{SrIII}$ and $16 \mathrm{SrV}$ group related phytoplasmas have rarely been detected in Poland (Cieślińska 2001; Kamińska and Śliwa 2008), they might be successfully vectored by the new insect species and become more widespread. Furthermore, the appearance of $O$. ishidae in Poland is associated with the risk of the introduction of phytoplasma diseases that have not yet been seen. 
The phytoplasma of the $16 \mathrm{SrV}$ group, which is associated with the flavescence dorée (FD) disease of grapevines in Spain, France, Italy, Germany, Switzerland, Serbia and Slovenia (Rosenberger and Jones 1978), was transmitted by specimens of $O$. ishidae under laboratory conditions to the vines (Lessio et al. 2016). The disease induces symptoms that include yellowing and downward rolling of the leaf margins and is included in the EPPO A2 list of pests recommended for regulation by quarantine. Presently Scaphoideus titanus Ball, 1932 is known to be the major vector of phytoplasma causing FD (Lessio et al. 2016), but the data on the salivary gland infestation of $O$. ishidae by phytoplasma suggest that this species might also be an important vector of FD and will perhaps be considered as a pest in Poland in the very near future. The phytoplasma of the $16 \mathrm{SrV}$ group was recorded in Poland on raspberry and blackberry (Cieślińska 2001). The presence of phytoplasma of the $16 \mathrm{SrV}-\mathrm{C}$ and $-\mathrm{D}$ groups in the bodies of $O$. ishidae was detected for the first time in Europe in Slovenia, in 2009 (Mehle et al. 2010). Later the pathogen of group $16 \mathrm{SrV}-\mathrm{D}$ was also detected in $16 \%$ of specimens of $O$. ishidae collected in vineyards in the Lombardy region of Italy (Gaffuri et al. 2011). The studies conducted by Gaffuri et al. (2011) revealed that the specimens of $O$. ishidae outnumbered those of well-known flavescence dorée vector Scaphoideus titanus Ball. The third report of FD phytoplasma infested mosaic leafhopper comes from Switzerland, in which the $16 \mathrm{SrV}-\mathrm{C}$ group was detected (Trivellone et al. 2015). Those results indicated an urgent need to assess the transmission potential of this quarantine pathogen by $O$. ishidae. A recent, comprehensive study on the $O$. ishidae confirms the mosaic leafhopper's ability to vector the FD disease (Lessio et al. 2016). The research was performed in vineyards of Piedmont, in Italy. Insects acquired the phytoplasma while feeding on infected plants under both laboratory and field conditions. In situ hybridization tests with the phytoplasma group $16 \mathrm{SrV}$ specific probe showed that the pathogen colonizes the salivary glands of the insects, which indicates that phytoplasma can be passed to the plants. However, only low efficiency of FD phytoplasma transmission to grapevines was observed. Additionally, it was shown that $O$. ishidae develops on the grapevine canes, which is evidence that grapevine is a feeding and reproductive host of the leafhopper.

Moreover, experiments conducted on O. ishidae in the 1970s confirmed the transmission of phytoplasma of the 16SrIII-A group ('Candidatus Phytoplasma pruni') to celeries (Rosenberger and Jones 1978). This phytoplasma is known as a causal agent of Peach $\mathrm{X}$ disease, which is common in North America but sporadic in Europe and Japan, and is considered to be a serious threat to trees and shrubs of the genus Prunus. Symptoms of this disease include changes in the color of leaf and fruit tissue, fruit deformation and shoot dieback (Davis et al. 2013). Phytoplasma of the 16SrIII group was detected only once in Poland in spruce tissue, but it has not been confirmed if it belongs to the same group as phytoplasmas causing drupaceous tree diseases (Kamińska and Śliwa 2008).

In the adjacent countries, where $O$. ishidae had been introduced earlier, it has expanded its range and the number of its localities has been increasing year by year. In Germany it has been found in a few dozen new localities since it was recorded for the first time in this country some years ago (Nickel 2010). The climate in Poland will probably favor this species and $O$. ishidae will become a permanent component of Polish fauna.

\section{Acknowledgements}

We are especially thankful to Dr Małgorzata Kalandyk-Kołodziejczyk (Department of Zoology of the University of Silesia) for her help in the translation of the text and Radosław Murat and Damian Bruder for collecting the insects and recording the data about this species.

\section{References}

Anonymous. 2012. Significant recent developments - New species. LEDRA - Newsletter of the Auchenorrhyncha Recording Scheme for Britain \& Ireland no. 2, 8 pp. Available on: http://www.ledra.co.uk [Accessed: December 15, 2015]

Anonymous. 2015. EPPO Global Database. Orientus ishidae: a potential phytoplasma vector spreading in the EPPO region. EPPO Reporting Service no. 05 - 2015 Num. article: 2015/098. Available on: https://gd.eppo.int/reporting/article-4763 [Accessed: December 15, 2015].

Anufriev G.A. 1978. Les Cicadelles de le Territoire Maritime. [Cicadellidae of the Russian Maritime Territory]. Horae Societatis Entomologicae Unionis Soveticae 60: 1-214. (in Russian)

Burakowski B., Mroczkowski M., Stefańska J. 1973. Chrząszcze Coleoptera - Biegaczowate - Carabidae. [Beetles Coleoptera - Ground beetles - Carabidae]. Part 1. Katalog Fauny Polski 23 (2): 1-232. (in Polish)

Callot H., Brua C. 2013. Insectes invasifs et envahissants en Alsace. [Invasive and non-invasive insects in Alsace]. Bulletin de l'Association Philomatique d'Alsace-Lorraine 44 (20102011): 21-44 et 132-140. (in French)

Cieślińska M. 2001. Preliminary results on detection of phytoplasmas associated with small fruit diseases in Poland. ISHS Acta Horticulturae 551: IX International Symposium on Small Fruit Virus Diseases: 87-92. DOI: 10.17660/ ActaHortic.2001.551.14

Davis R.E., Zhao Y., Dally E.L., Lee I.M., Jomantiene R., Douglas S.M. 2013. 'Candidatus Phytoplasma pruni', a novel taxon associated with X-disease of stone fruits, Prunus spp.: multilocus characterization based on $16 \mathrm{~S}$ rRNA, secY, and ribosomal protein genes. International Journal of Systematic and Evolutionary Microbiology 63 (2): 766-776. DOI: 10.1099/ ijs.0.041202-0

Gaffuri F., Sacchi S., Cavagna B. 2011. First detection of the mosaic leafhopper, Orientus ishidae, in northern Italian vineyards infected by the flavescence dorée phytoplasma. New Disease Reports 24: 22. DOI: 10.5197/j.2044-0588.2011. 024.022. 
Guglielmino A. 2005. Observations on the genus Orientus (Rhynchota Cicadomorpha Cicadellidae) and description of a new species: O. amurensis n. sp. from Russia (Amur Region and Maritime Territory) and China (Liaoning Province). Marburger Entomologische Publikationen 3 (3): 99-110 Available on:. http://dspace.unitus.it/handle/2067/1570 [Accessed: December 15, 2015].

Günthart H., Mühlethaler R. 2002. Provisorische Checklist der Zikaden der Schweiz (Insecta: Hemiptera, Auchenorrhyncha). [Provisional checklist of cicadas of Switzerland (Insecta: Hemiptera, Auchenorrhyncha)]. Denisia 4, Zugleich Kataloge des OÖ. Landes museums, Neue Folge 176: 329-338. (in German)

Hamilton K.G.A. 1983. Introduced and native leafhoppers common to the Old and New worlds (Rhynchotha: Homoptera: Cicadellidae). Canadian Entomologist 115: 473-511. DOI: 10.4039/Ent115473-5

Hamilton K.G.A. 1985. Leafhoppers of ornamental and fruit trees in Canada. Agriculture Canada Publication 1779E/F: 1-71. DOI: $10.5962 /$ bhl.title.59468

Ishihara T. 1968. Hemipterous fauna of the Japan Archipelago. Transactions of the Shikoku Entomological Society 10 (1): $18-28$.

Jurc M. 2010. Some harmful native and non-native insects in the forests of the Ljubljana area. (Gozdovi and Mestniobcini Ljubljana (Forests in the Municipality of Ljubljana)). Gozdarski Vestnik 68 (5/6): 321-329. Available on: https://www. dlib.si/details/URN:NBN:SI:doc-R8WVBWN1 [Accessed: December 15, 2015]. (in Slovenian)

Kamińska M., Śliwa H. 2008. Diseases of coniferous trees associated with phytoplasma infection. Progress in Plant Protection 48 (1): 183-189. (in Polish, with English summary)

Koczor S., Bagarus A.K., Karap A.K., Varga A., Orosz A. 2013. A rapidly spreading potential pest, Orientus ishidae identified in Hungary. Bulletin of Insectology 66 (2): 221-224.

Łabanowski G.Sz., Soika G. 1998. Dangerous pests for ornamental trees and shrubs. Progress in Plant Protection 38 (1): 172-179. (in Polish, with English summary)

Lessio F., Picciau L., Gonella E., Mandrioli M., Tota F., Alma A. 2016. The mosaic leafhopper Orientus ishidae: host plants, spatial distribution, infectivity, and transmission of $16 \mathrm{SrV}$ phytoplasma to vines. Bulletin of Insectology 69 (2): 277-289.

Lubiarz M., Musik K. 2015. First record in Poland of the Ligurian leafhopper, Eupteryx decemnotata Rey 1891 (Cicadomorpha, Cicadellidae) - an important pest of herbs. Journal of Plant Protection Research 55 (3): 324-326. DOI: 10.1515/ jppr-2015-0030.

Malenovsky I., Lauterer P. 2010. Additions to the fauna of planthoppers and leafhoppers (Hemiptera: Auchenorrhyncha) of the Czech Republic. Acta Musei Moraviae, Scientiae Biologicae (Brno) 95 (1): 49-122.

Mazzoni V. 2005. Contribution to the knowledge of the Auchenorrhyncha (Hemiptera: Fulgoromorpha and Cicadomorpha) of Tuscany (Italy). Redia 88: 85-102.

Mehle N., Seljak G., Rupar M., Ravnikar M., Dermastia M. 2010. The first detection of a phytoplasma from the $16 \mathrm{SrV}$ (Elm yellows) group in the mosaic leafhopper Orientus ishidae. New Disease Reports 22: 11. https://doi.org/10.5197/j.2044$-0588.2010 .022 .011$

Metcalf Z.P. 1967. General Catalogue of the Homoptera. Fasc. VI. Cicadelloidea. Part 10. Euscelidae. Section 1 Agricultural Research Service, United States Department of Agriculture, Washington, D.C.L: 1077 pp.

Nickel H. 2010. First addendum to the leafhoppers and planthoppers of Germany (Hemiptera: Auchenorrhyncha). Cicadina 11: 107-122.

Oman P.W. 1949. The Nearctic leafhopper (Homoptera Cicadellidae). A generic classification and check list. Memoirs of the Entomological Society of Washington 3: 253 pp.

Rosenberger D.A., Jones A.L. 1978. Leafhopper vectors of the Peach $\mathrm{X}$ disease pathogen and its seasonal transmission from chokecherry. Phytopathology 68: 782-790. DOI: 10. 1094/phyto-68-782

Sanders J.G., DeLong D.M. 1919. Eight new "Jassids" from the eastern United States. Family Cicadellidae (Hemiptera Homoptera). Annals Entomological of Society of America 12: 231-237. DOI: 10.1093/aesa/12.3.231

Seljak G. 2004. Contribution to the knowledge of planthoppers and leafhoppers of Slovenia (Hemiptera, Auchenorrhyncha). Acta Entomologica Slovenica 12: 189-216.

Świerczewski D., Stroiński A. 2011. The first records of the Nearctic treehopper Stictocephala bisonia in Poland (Hemiptera: Cicadomorpha: Membracidae) with some comments on this potential pest. Polish Journal of Entomology 80 (1): 13-22. DOI: 10.2478/v10200-011-0002-7

Trivellone V., Filippin L., Jermini M., Angelini E. 2015. Molecular characterization of phytoplasma strains in leafhoppers inhabiting the vineyard agroecosystem in Southern Switzerland. Phytopathogenic Mollicutes 5 (1): 45-46. DOI: 10.5958/ 2249-4677.2015.00018.3

Vilbaste J. 1968. Systematic treatise of Cicadas found on the edge of the coastal regions. Über die Zikadenfauna des Primorje Gebietes. Izdatel'stvo „Valgus“, Tallin, 195 pp.

Walczak M., Musik K., Mokrzycka A. 2012. Japananus hyalinus (Osborn, 1900) a new leafhopper for Polish fauna (Hemiptera: Cicadomorpha). Wiadomości Entomologiczne 31 (4): 242250. Available on: http://pte.au.poznan.pl/we/2012/WE31-4_06_walczak_i_in.pdf [Accessed: December 15, 2015]. 